\title{
NTHL1 Gene
}

National Cancer Institute

\section{Source}

National Cancer Institute. NTHL1 Gene. NCI Thesaurus. Code C106190.

This gene plays a role in nucleotide-excision DNA repair. 